\title{
A forgotten collection: the Libyan ethnobotanical exhibits (1912-14) by A. Trotter at the Museum O. Comes at the University Federico II in Naples, Italy
}

Antonino De Natale ${ }^{1 *}$ and Antonino Pollio ${ }^{2}$

\begin{abstract}
Background: The Ethnobotanical Collection from the Libyan territories of the botanist Alessandro Trotter is included in the Oratio Comes Botanical Museum at the Faculty of Agraria at the University Federico II in Naples. Trotter explored different territories of Libya, mainly Tripolitania, between 1912-1924, collecting plant specimens and the drugs most frequently sold in the markets. The Libyan herbarium currently includes over 2300 sheets of mounted and accessioned plants. The drugs, mostly acquired by Trotter from Tripolitanian markets, were identified and packed in 87 paper sheets or boxes. Trotter added ethnobotanical information for each species when available.

Methods: A database of the herbarium species and the drugs has been carried out, after a taxonomic update. Nomenclature has been revised according to the African flowering plants database and the World Checklist of selected plant families, and a comparison with currently available ethnopharmacological data from North African has been attempted.

Results: In this study, ethnopharmacological data related to about 80 species of flowering plants and to 4 lichens are presented. The plants are mainly from Mediterranean or Sub-Saharan habitats and belong to 37 different families; Lamiaceae was the most cited family, with 10 accessions. Generally, the aerial parts of the plants are the most frequently used (28 species), followed by leaves (15 species), flowers and seeds ( 9 species), fruits (7 species) and hypogean organs (roots, rhizomes, tubers: 5 species). Plants were generally processed in very simple ways: infusion or decoction of the plants were prepared and orally administered or used for topical applications. A wide range of conditions was treated, ranging from mental disorders to skin affections. All the organs of human body are considered, but the pathologies of gastro-intestinal tract, respiratory system and those related to traumatic accidents were the most frequently mentioned. The comparison with the recent ethnopharmacological research in Maghreb and its neighboring countries reveals a high correspondence; almost all the plants cited by Trotter are still used in the folk medicine of at least one of the North African countries, and the therapeutic uses of each plant appear consistent over time.
\end{abstract}

Conclusions: The information collected by Trotter is an important contribution to tracing plant utilization in Libyan folk medicine over the last century.

Keywords: Herbarium, North Africa, Libya, Traditional plant use, Medicinal plants

\footnotetext{
* Correspondence: denatale@unina.it

${ }^{1}$ Department of Soil, Plant, Environmental and Animal Production Sciences,

University of Naples (Federico II), Via Università, 100, 80055 Portici (NA), Italy

Full list of author information is available at the end of the article
} 


\section{Background}

The Orazio Comes Botanical Museum at the Facoltà di Agraria dell'Università Federico II di Napoli encompasses the Historical Library, the Herbarium Porticense (PORUN), the Mycological Herbarium (POR) and wood collections (Xilotomoteque and Xiloteque). These wideranging collections were created in the course of the 19th and 20th Centuries and were kept in different sections of the Faculty of Agraria. Only recently was the Polo Museale delle Scienze Agrarie instituted, with the aim of unifying all the collections under a common structure. While the definitive building is under re-construction, the collections of the O. Comes Museum have been temporarily transferred to a provisional site. This on-going reorganization provided an opportunity for a careful examination of the items from each collection, including the archives, which document the work of various botanists from the early 1600 s to 1940 [1-3]. One of the most interesting results of this work was the rediscovering of the Botanical Collection from the Libyan territories of the botanist Alessandro Trotter (Figure 1). A. Trotter was born on 1874 in Udine, Italy. In 1899 , he graduated with a degree in Botany from the University of Padua, under Professor A. Saccardo, who accepted him as his assistant immediately after his graduation. A. Trotter remained at the University of Padua until 1902, when he was entrusted to teach Plant Pathology at the School of Enology of Avellino, and, subsequently, at the Agronomy Faculty of Portici, Naples, where he worked until 1949 as full professor of Botany. Trotter's scientific career reflected his broad interest in Botany. Since his beginning at the University of Padua, he demonstrated a strong attitude towards the floristic, with a specific interest in mycology, but he was also committed to the study of horticultural species, particularly those from South Italia. On behalf of the Italian Government, from 1912 to 1924, Trotter participated in different expeditions in Libya [4] (Figure 2), mainly in Tripolitania [5-7]. The results of Trotter's work in this region and, to a lesser extent, in other Libyan territories was a collection of plant specimens and a repertorium of the drugs he bought in the markets of Tripolitania, together with an archive of information, field notes, and photographs. Some of his findings were published in two reports $[8,9]$, which are unavailable to the current scientific community. Over time, Trotter's materials were scattered throughout different rooms of the Botany Department and merged with other accessions belonging to different collections. The organization of the new museum offered the possibility of grouping Trotter's exhibits in one collection, which represents a unique source of ethnobotanical information, dating back to a century ago, on a scarcely known geographical area of North Africa. It has been stressed that there are only a few places in the world for which diachronic data for ethnopharmacological purposes are available [10]. Recent efforts on this subject have been recently presented for Estonia [11] and Poland [12,13], but old ethnobotanical data are very scarce for the African continent $[14,15]$.

The aim of this paper is to report the data on plants used in folk medicine of Tripolitania and neighboring regions collected by Trotter during his expeditions in Libya and to present a preliminary description of the exhibits now available in the Libyan ethnobotanical collection of the Orazio Comes Museum.

\section{Methods}

\section{Geographical description of the study area}

North Tripolitania is dominated by the Jaffar Plain, which slopes downward to the west and upward to the highland territories (Jabel Nafusa), which in turn continue eastward with a belt of hills around Tarhuna and Homa [16]. The vegetation is dominated by steppes, which cover a zone extending from the coast west of Zamiya to a large part of Jaffara Plain, the Jabal Nafusa, and eastward to the Misurata region [17]. The soils around Tripoli, extending to central Jaffara, are rich in organic compounds, but the soils are poor and sandy in the rest of North Tripolitania and rocky in Jabal Nafusa. In coastal Tripolitania and in the Jabal Nafusa highlands, the climate is Mediterranean, with long, dry and hot summers, whereas in central and eastern Jaffara and in inland Jabal, the climate is semi arid, and drought occurs frequently [18]. At the beginning of 20th century, agriculture was concentrated in the oasis of the coastal territories and in part of the Jabal Nafusa plain. In the rest of the region, pastoralism (sheep, goats and camels) was the most common land use, together with transhumant cereal cultivation. The areas of mixed cereal cultivation and pastoralism were held by seminomadic groups through a combination of private and collective tenure [16].

\section{History of the Trotter Libyan Collections}

After his first expedition to Libya (1912), Trotter assembled a collection of plants primarily from North Tripolitania. In the subsequent trips, he gathered specimens from other regions of Libya as well [5-7].

The Trotter Collection, now located in the Orazio Comes Museum, features herbarium samples, drugs, historical photographs, and manuscripts.

The Libyan Fanerogamic collection currently includes over 2300 sheets of mounted and accessioned plants. The herbarium is organized alphabetically by family, and each herbarium sheet measures $43 \times 28$ centimeters 


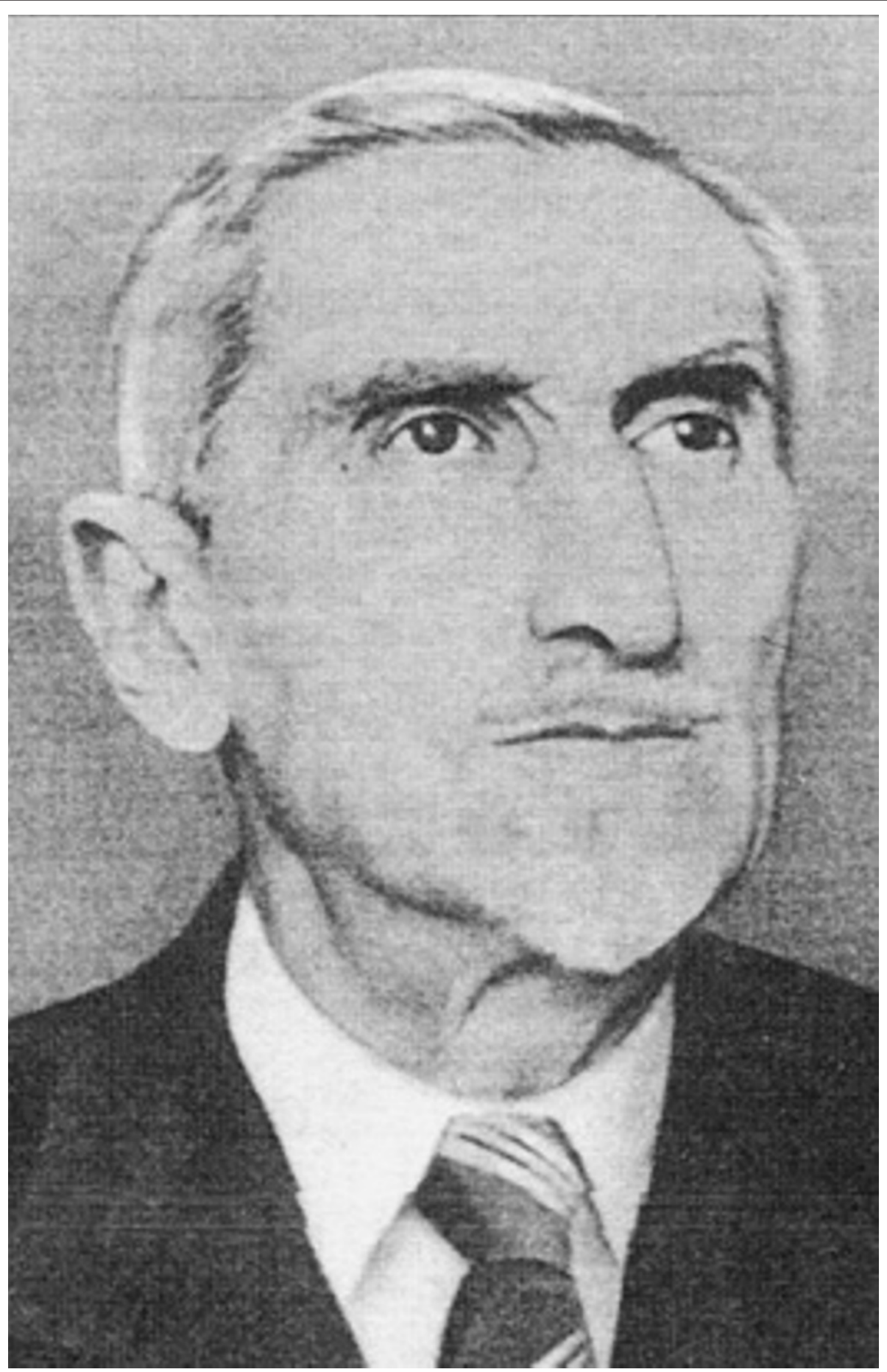

Figure $1 \mathrm{~A}$ portrait of Alessandro Trotter.

(Figure 3). Paper specimen labels are attached to the right corner of the herbarium sheet. Loose parts or fragments of plant organs are included in envelopes attached to the herbarium sheet. Each voucher specimen was annotated by Trotter with the current taxonomic name at the time, the Libyan location from which the specimen was acquired, and the collection date. Additionally, Trotter added ethnobotanical information for about 80 species, which have now been grouped in a specifically designed archive.

The drugs (Figure 4), prevalently acquired by Trotter from Tripolitania markets, were identified and packed 


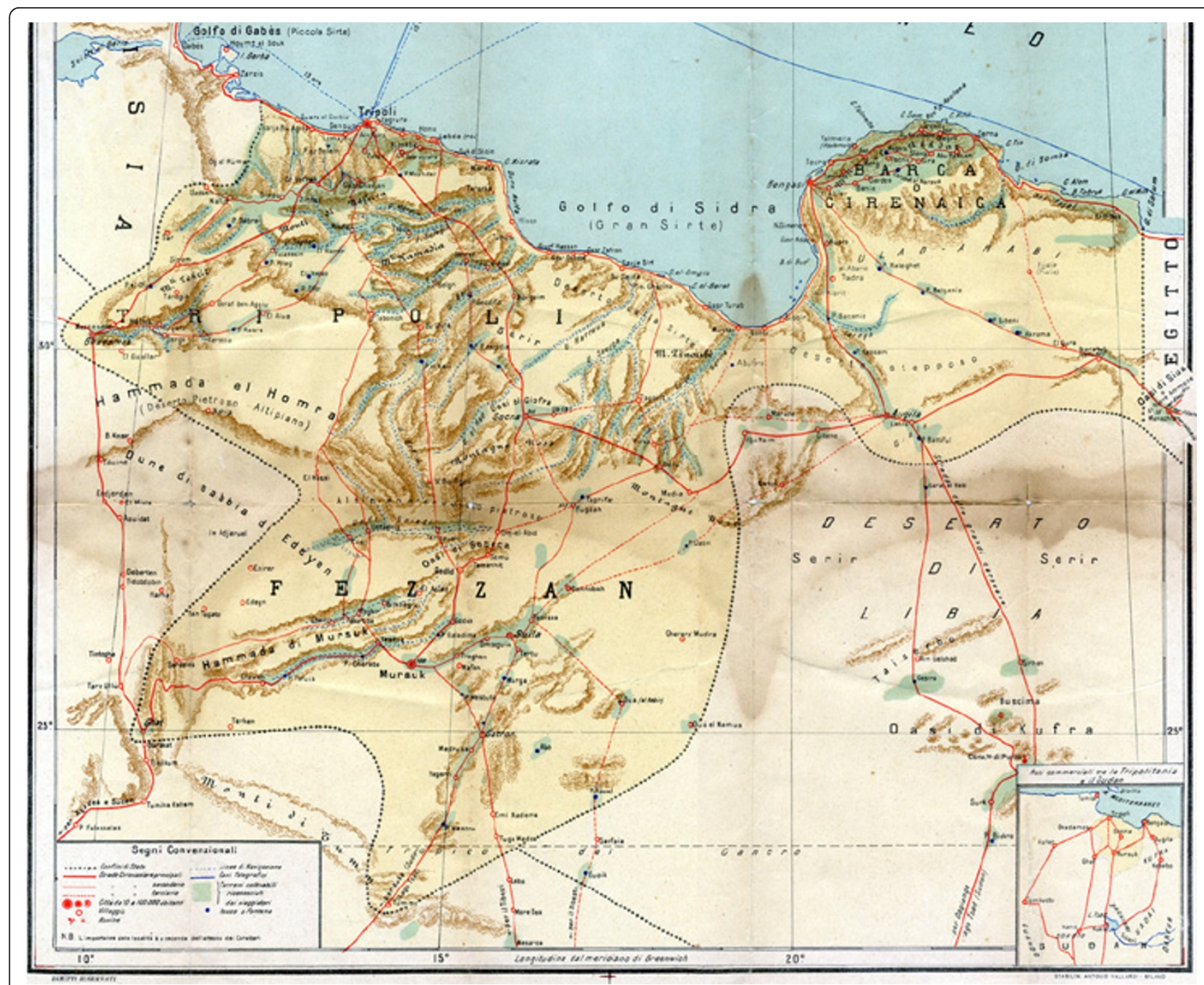

Figure 2 Geographical map of Libya in 1912 [4]

by Trotter in 83 paper sheets or boxes (Figure 5), which were stored in a wooden cupboard (Figure 6). Included in the collection were some unidentified drugs, corresponding to $\mathrm{n} .74$ and 83 .

Recently, a database of the herbarium species and drugs has been carried out, and, subsequently, a taxonomic update has been attempted. The nomenclature has been revised according to the African flowering plants database [19] and the World Checklist of selected plant families [20].

\section{Results}

Italian colonization of Tripolitania began in 1911 without a preliminary assessment of the land: for this reason, geographical expeditions in Libyan territories were undertaken between 1912 and 1916, with the participation of various specialists. The first expedition [5] had the task of carrying out mineralogical and agronomic studies on
Tripolitania, and Trotter was the agronomist of the expedition. During his residence in Libya, he studied the flora (algae, fungi, and higher plants, including cultivated species) of Tripolitania. He was also greatly involved in the collection of information on plant uses from the local people. This interest was driven by practical needs, as plants used by Libyans could have potential economic benefits to emigrant settlers. In this paper, we have concentrated our attention on the medicinal uses of Libyan plants collected by Trotter. In Table 1[21-45], these ethnopharmacological data are compared with the recent available information from Libya and other neighboring countries.

Trotter collected his ethnobotanical data mainly during the first expedition (1912). The provenance of the information is not always indicated, but we are far from the present standards of ethnobotanical investigations. Frequently, a single or very few informants are the source of the data, and, in some cases, Trotter reported 


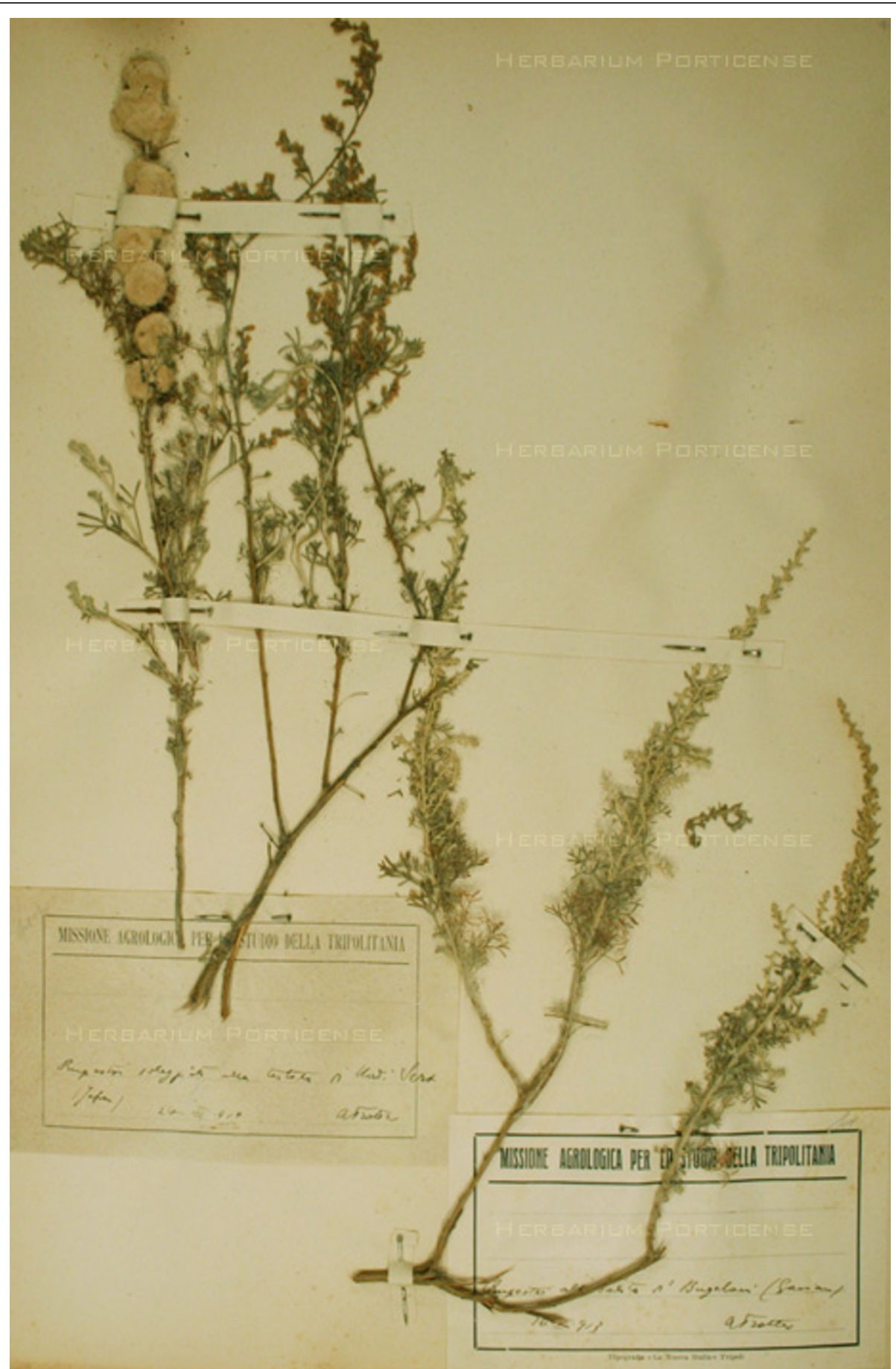

Figure 3 Herbarium specimen from Trotter collection, Artemisia herba-alba Asso.

only that the plant was used as a medicine, without describing the therapeutic applications. Notwithstanding these limitations, a not-irrelevant body of knowledge was assembled.

Data are related to about 70 species of flowering plants and to 4 lichens. The plants are mainly from
Mediterranean or Sub-Saharan habitats, with a slight prevalence for the former. The plants belong to 37 different families; Lamiaceae was the most cited family with 10 accessions, followed by Asteraceae with 9. The prevalence of these families has been reported in the conclusive report of the Rubia project on medicinal 


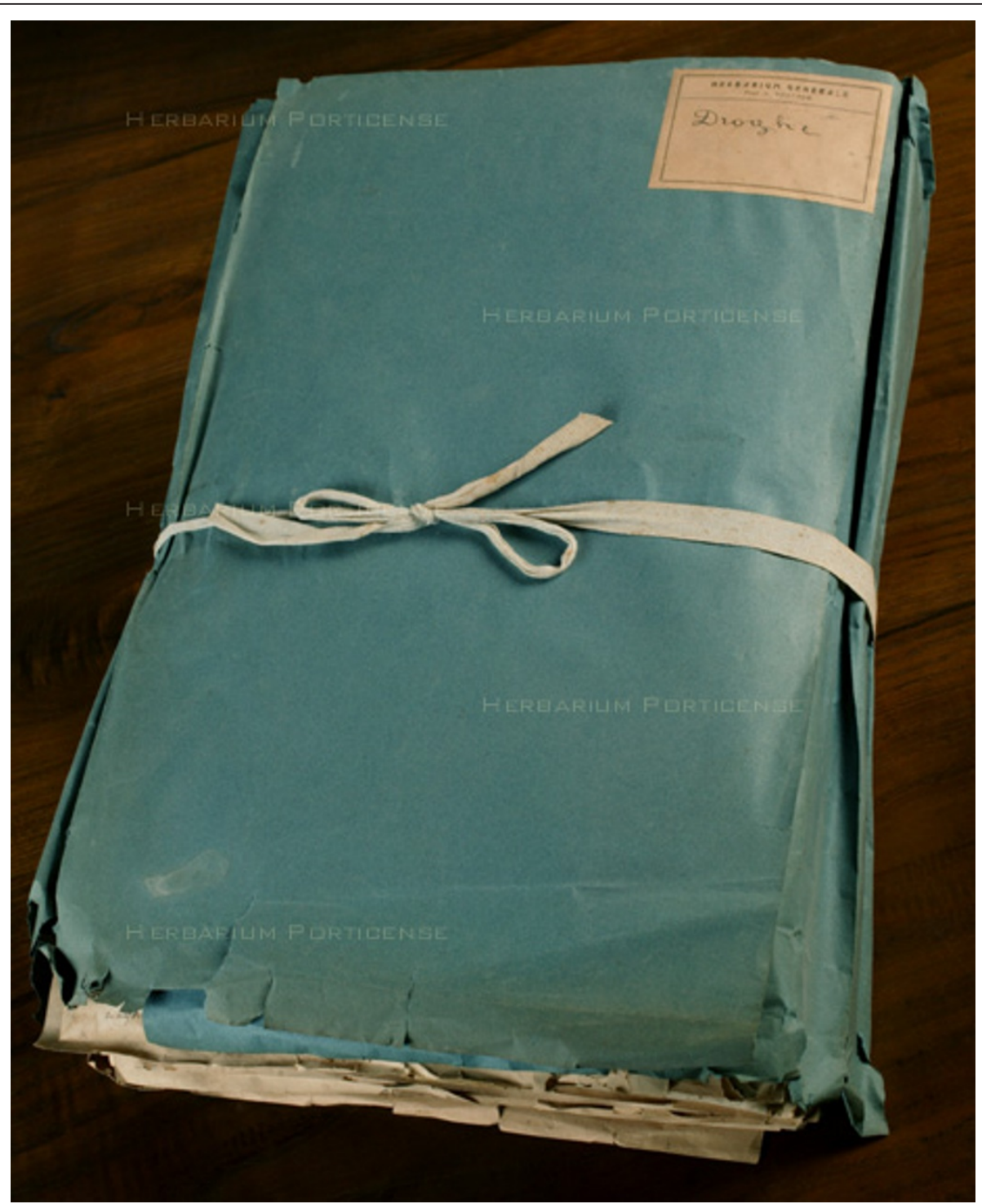

Figure 4 A drug package.

plants in Mediterranean area [46]. The authors suggest that this could be because the plants belonging to these families are easily recognizable by the morphology of the flowers and due to their aromas and flavors.

Generally, the aerial parts of the plants are the most frequently used (28 species), followed by leaves (15 species), flowers and seeds (9 species), fruits (7 species) and hypogean organs (roots, rhizomes, tubers: 5 species).

Plants were generally processed in very simple ways: an infusion or decoction of the plants were prepared and orally administered or used for topical applications. A wide range of affections was treated, ranging from mental disorders to skin affections. All the organs of human body were considered, but the pathologies of the gastro-intestinal tract, respiratory system and those related to traumatic accidents (contusions, swellings, burnings, wounds) were the most frequently mentioned.

Trotter described a decoction, named sciba, made with three different lichens belonging to the genera Evernia and Ramalina. The species mentioned are found worldwide and largely used for dyeing [47], but the species are also used in perfumery [48] and in traditional medicine of numerous countries, due to the presence of active compounds, as usnic acid and atranorin [49]. Trotter did not indicate the therapeutic applications for this decoction. With a similar name, al-sheba, the lichen Parmotrema tinctorium is sold as food spice in India [50]. As far we know, there are no other reports dealing with this preparation in the Maghreb countries. 


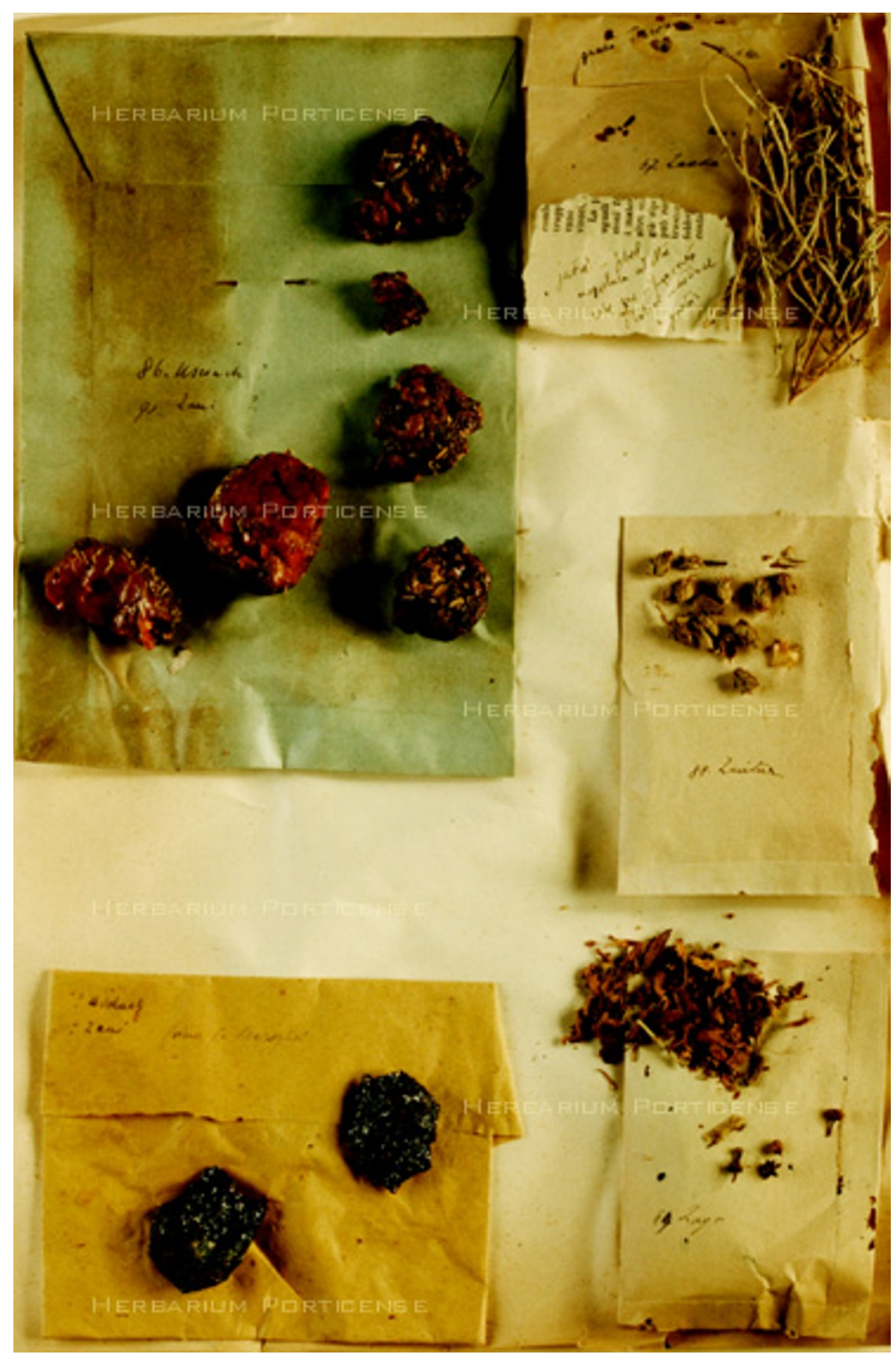

Figure 5 Paper sheets and boxes containing the drugs.

Overall, 75 plants (including the four lichens previously mentioned) were also collected as drugs by Trotter; 30 of these had medicinal properties. Two mineral samples (antimony and clay) were also held in the drug collection (Figure 7 and 8); they were used in topical wound treatment by numerous ancient and primitive societies [51]. The drugs were mainly sold in the Tripoli market, but also in local markets spread along Tripolitania. Libya is located in the middle of Mediterranean and was an important crossroad for trade in ancient times. The Libyan towns established commercial relationships with countries of all three continents, Africa, Asia and Europe. The town of Cyrene was a prime center for the export of the medicinal herb called silphium, one of the 


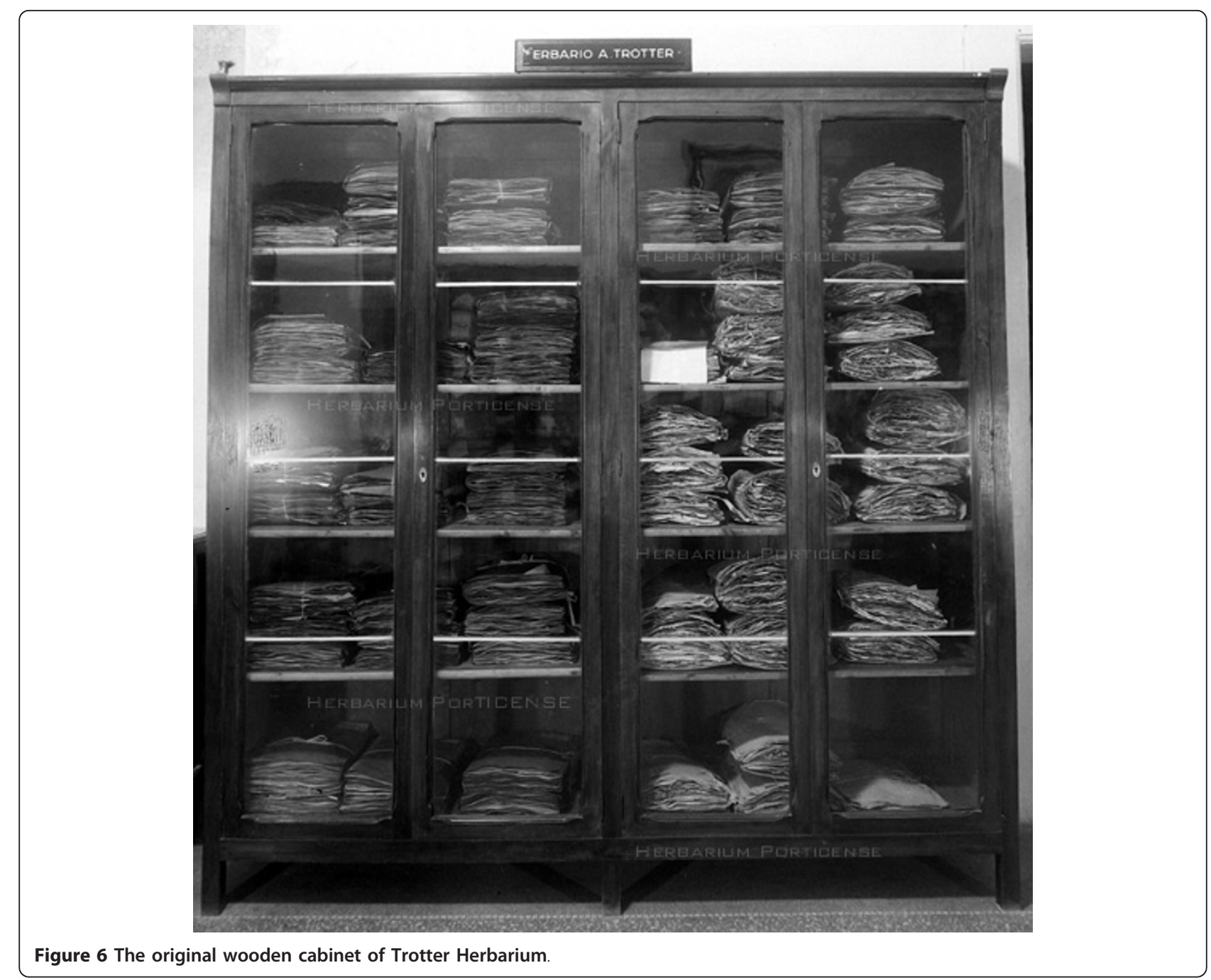

essential commodities of the Mediterranean region in classical era [52]. A late echo of the ancient flourishing trades was still present in the drugs found by Trotter at the beginning of the 20th century. He collected drugs that are, to a large extent, of Mediterranean origin, and are currently traded in Mediterranean region. Drugs from herbs such as Ajuga iva or Artemisia arborescens or those belonging to the genera of Lamiaceae, listed in Table 1, are commonly found in the markets along the Mediterranean, from Moroccan bazaars [44] to the herbal shops of Turkey [40] and Greece [53]. In contrast, some drugs were of Asiatic provenance, such as Alpinia officinarum [54] and Piper retrofractum [55], whereas others, such as Tanacethum parthenium, came mainly from Europe [56], suggesting that the ancient trade routes from Asia and Europe to North Africa were still being used a century ago. Few drugs were produced from indigenous plants; perhaps the most interesting case is that of Ferula marmarica, a plant native to some
Libyan regions [34], which was used in classical times to produce the ammoniac gum [35], to which Dioscorides attributed relevant therapeutic roles ranging from antiinflammatory to digestive and painkiller [57].

\section{Conclusion}

The Trotter Collection can represent a useful tool for current ethnopharmacological research in Libya and neighboring countries. It is known that about $80 \%$ of the African population presently rely on traditional forms of health care, but it is not easy to document continuity and changes in therapeutic approaches. The information collected by Trotter contributes to filling this gap, enabling us to trace the use of plant utilization in Libyan folk medicine over the last century. A comparison with the recent ethnopharmacological research in Maghreb reveals a high correspondence; almost all of the plants cited by Trotter are still used in the folk medicine of at least one of the North African countries, and 
Table 1 Plants used in Libyan folk therapy at the beginning of XXth Century according to Trotter data.

\begin{tabular}{|c|c|c|c|c|}
\hline Botanical name & Local names & Part(s) used & Description of uses & Present uses in Libya and neighboring Countries \\
\hline $\begin{array}{l}\text { Aaronsohnia pubescens } \\
\text { (Desf.) K. Bremer et } \\
\text { Humphries (PORUN - } \\
\text { TTF2300) } \\
\text { ASTERACEAE }\end{array}$ & $\begin{array}{l}\text { uàs-uàsa (arab); uscescuane } \\
\text { (tuaregh) }\end{array}$ & Leaves & $\begin{array}{l}\text { Grounded and eaten against gastro-intestinal } \\
\text { aches }\end{array}$ & $\begin{array}{l}\text { The whole plant in infusion is used for gastro-intestinal troubles } \\
\text { and kidney stones. It is collected and sold in the markets of South } \\
\text { Algeria [21] }\end{array}$ \\
\hline $\begin{array}{l}\text { Achillea maritima (L.) Ehrend. } \\
\text { et Y.P. Guo (PORUN - } \\
\text { TTF2318) } \\
\text { ASTERACEAE }\end{array}$ & agbita, sciba (Algeria) & Aerial part & Sold as a febrifuge and emmenagogues & $\begin{array}{l}\text { In Marmarica, it is known as medicinal plant [22]. In North African } \\
\text { countries, the flowering branches are considered a febrifuge, } \\
\text { emmenagogue, tonic, and taenifuge [23] }\end{array}$ \\
\hline $\begin{array}{l}\text { Ajuga iva (L.) Schreb. } \\
\text { (PORUN - TTD52; TTF1411) } \\
\text { LAMIACEAE } \\
\text { Additional file } 1\end{array}$ & $\begin{array}{l}\text { sciandagúra (arab); assaron? } \\
\text { (Cirenaica); tletúl teelscín } \\
\text { (berber) }\end{array}$ & Aerial part & $\begin{array}{l}\text { A cold infusion is anthelminthic; mixed with } \\
\text { other components, against pulmonary affections }\end{array}$ & $\begin{array}{l}\text { In Marmarica, the plant is considered medicinal [22]. A decoction of } \\
\text { the aerial parts is administered against rheumatic pains, and as a } \\
\text { carminative and stomachic. Aerial parts are also used as incense in } \\
\text { ritual practices [24]. In Morocco, the hot infusion is considered } \\
\text { antidiabetic [23]; also used as an anthelmintic and for intestinal } \\
\text { disorders [25]. Crushed leaves and seeds are smoked for their } \\
\text { narcotic effects [26] }\end{array}$ \\
\hline $\begin{array}{l}\text { Aloë vera L. (PORUN - } \\
\text { TTF2331) } \\
\text { ASPHODELACEAE }\end{array}$ & sabbàr & Leaf juice & Medicinal properties (not described) & $\begin{array}{l}\text { The transparent gel from leaf pulp is used as a vulnerary and } \\
\text { laxative in different African countries [27] }\end{array}$ \\
\hline $\begin{array}{l}\text { Alpinia officinarum Hance } \\
\text { (PORUN - TTD17) } \\
\text { ZINGIBERACEAE } \\
\text { Additional file } 2\end{array}$ & cúlgan, cúlgian & Rhizome & Tonic & $\begin{array}{l}\text { Drug imported from East Asia and used in Egypt and Morocco, } \\
\text { used as an antitussive and stimulant [22,25]. A preparation from the } \\
\text { root is used for rheumatism and sexual impotence [24] }\end{array}$ \\
\hline $\begin{array}{l}\text { Arbutus unedo L. (PORUN - } \\
\text { TTF895) } \\
\text { ERICACEAE }\end{array}$ & $\begin{array}{l}\text { sc'meri (arab); linz (Algeria); } \\
\text { isisnu, sciscnu (berber) }\end{array}$ & $\begin{array}{l}\text { Bark of roots } \\
\text { and leaves }\end{array}$ & Astringent & The decoction of leaves or raw fruits to treat kidney diseases [26] \\
\hline $\begin{array}{l}\text { Artemisia arborescens L. } \\
\text { (PORUN - TTD51) } \\
\text { ASTERACEAE } \\
\text { Additional file } 3\end{array}$ & sézeret Marian (arab); scih & $\begin{array}{l}\text { Young } \\
\text { shoots, } \\
\text { flowers, } \\
\text { leaves }\end{array}$ & A decoction against intestinal affections & $\begin{array}{l}\text { In Morocco, the plant is considered anthelmintic, aperitive, diuretic, } \\
\text { emmenagogue and abortive [25]. A leaf infusion to treat common } \\
\text { colds, vertigo, and helminthiasis. Powdered leaves are externally } \\
\text { applied for skin infections and wrinkles [24] }\end{array}$ \\
\hline $\begin{array}{l}\text { Artemisia campestris L. subsp. } \\
\text { variabilis (Ten.) Greuter } \\
\text { (PORUN - TTF484) } \\
\text { ASTERACEAE }\end{array}$ & $\begin{array}{l}\text { sc'ahâl (arab); togoft, tegoft, } \\
\text { taghert, tâghiat (berber); } \\
\text { teghoch (tuaregh) }\end{array}$ & $\begin{array}{l}\text { Flowers, } \\
\text { leaves }\end{array}$ & Anthelminthic, known as dua lehnâsc & $\begin{array}{l}\text { In Algeria, it is used as a substitute for A. absinthium [23]. In Tassilli } \\
\text { N'ajjer (South Algeria), aerial parts and flowers are used for post- } \\
\text { partum care, emmenagogue, analeptic, and antispasmodic. Also } \\
\text { used as an anthelminthic, for stomach and liver affections. Vulnerary } \\
{[28]}\end{array}$ \\
\hline $\begin{array}{l}\text { Artemisia herba-alba Asso } \\
\text { (PORUN -TTF482) } \\
\text { ASTERACEAE } \\
\text { Figure } \mathbf{3}\end{array}$ & $\begin{array}{l}\text { scih (arab); aghares (berber); } \\
\text { azezzeré, zezzeri (temahac) }\end{array}$ & $\begin{array}{l}\text { The whole } \\
\text { plant and the } \\
\text { inflorescence }\end{array}$ & $\begin{array}{l}\text { In the Fezzan, the dried plant is ground and } \\
\text { used as a stomachic }\end{array}$ & $\begin{array}{l}\text { In Marmarica region, it is known as fodder and as a medicinal plant } \\
\text { [22]. A potion of the plant is drunk in North Sahara against } \\
\text { digestive troubles, as an anthelmintic, and to treat eye affections } \\
\text { and obesity [29]. A branch decoction is used for rheumatic pains } \\
\text { and helminthiasis [24]. In Morocco, the plant is administered against } \\
\text { gastrointestinal affection, as an antiseptic, anthelmintic, antidote to } \\
\text { poisons, hypoglycemiant and emmenagogue [25] }\end{array}$ \\
\hline $\begin{array}{l}\text { Asphodelus refractus Boiss. } \\
\text { (PORUN - TTF2304) } \\
\text { ASPHODELACEAE }\end{array}$ & not reported & Leaves & Diuretic & $\begin{array}{l}\text { Roots, shoots and leaves are used from Egypt to Morocco as a } \\
\text { tonic and stomachic, against headache, liver affections } \\
\text { rheumatisms, and for treatment of syphilis [23] }\end{array}$ \\
\hline
\end{tabular}


Balanites aegyptiaca (L.) Del. S.I. (PORUN - TTF2302) BALANITACEAE

\section{hagilidi, heglig (arab); tebôrac (temahac); tsciaisciot (Tuat);} addua (Haussa)

Young leaves,
pulp of fruits

Leaves to clean sores; pulp fruit used in spleen

Leaves to clean sores; pulp fruit used in
diseases and to kill Guinea worms (Vena medensis)

Boswellia sacra Flüeckiger

(PORUN - TTD39; TTF2305)

lúban

BURSERACEAE

Additional file 4

Brassica napus L. s.l. (PORUN léft (arab); afrân (temahac)

- TTF2308)

BRASSICACEAE

Capparis orientalis Veillard in cábbar (arab); tilult (berber) Duh. (PORUN - TTD7:

TTF101)

CAPPARACEAE

Additional file 5

Citrullus colocynthis (L.)

Schrad. (PORUN - TTF2316)

CUCURBITACEAE

Coriandrum sativum L.

(PORUN - TTF2313)

APIACEAE

Cuminum cyminum $\mathrm{L}$.

(PORUN - TTD9)

APIACEAE

Additional file 6

Cupressus sempervirens L.

(PORUN - TTD60; TTF854)

CUPRESSACEAE

Additional file 7

Curcuma longa L. (PORUN -

TTF2320)

ZINGIBERACEAE

Cymbopogon schoenanthus

(L.) Spreng. s.l. (PORUN -

TTD79)

POACEAE

Additional file 8

Cynodon dactylon (L.) Pers.

(PORUN - TTF1127)

POACEAE handel, handla (arab):

taghillilut (berber); tassellet

(mezabita); alched, hagi

(tuaregh)

cússbur, cóssbor (arab)

Fruits

chemún ahdar (arab); azcar (tuaregh)

arz, sirùa (arab)

An infusion against cough and heart diseases

Roots

Medicinal properties (not described)

led'her (Mizda, arab); bu'rucûba semmad (Algeria); lemmed tiberrimt, leberint (Algeria)

Fumigation against a kind of influence called ahón

négem (arab); tobbalt (berber); Whole plant The decoction is a diuretic asezmir (mezabita); oscerar (temahac) Afric is used in the central Sahara (Algeria) and in other North African countries, as an anthelminthic, against skin affections, and as a vulnerary. Also administered to cure stomach, liver, pulmonary and spleen affections [23,28]. In Sudan, the fruit is administered as a purgative, a bark decoction against jaundice, and branch fumigation against rheumatisms [30]. Also used as purgative and for bilharzias [31]

The species grows in South Arabia and is known by the Arabians as "maghrayt d'sheehaz". The resin is traditionally sold in African markets as a disinfectant and also used in the preparation of cosmetics [32]

Included among Libyan medicinal plants as an emollient (roots) [33]

In North Sahara, it is administered as a pain-killer, mainly to treat toothaches, and against rheumatisms [29]. In central Sahara (Tassili N'ajjer, Algeria), a poultice of fresh leaves is topically applied against rheumatism pains and headache [28]. Flowers and fruits are macerated to treat rheumatism [26]. An infusion of root bark is used as a cholagogue [24]

Roots are used as an abortive. In Morocco, it is considered as a antiepileptic, anthelmintic, aphrodisiac, and hypoglycemiant. Also administered against gonorrhea and tinea [25]. Moreover, the fruit, broken into small pieces, is used to protect woolen clothing from moths [21]

Aphrodisiac, anti-inflammatory, tonic. Seed and leaf decoction used against kidney stones, intestinal pains, insomnia, and scurvy $[25,26]$. Fruits are placed onto fire to remove bad spirits [24]

A milk infusion of fruit is administered against gastric pains and as an intestinal antiseptic, carminative and sudorific [24,25]. Also used in veterinary medicine [23]

In Libya, Morocco and Tunisia, the cones are considered antidiarrheal, antihemorrhagic, astringent, diuretic, expectorant, and sudorific [23]. In the El-Jabal El-Akhdar region (Libya), leaves and cones are administered in different ways against asthma, piles, and vaginal discharge [34]

in Morocco, it is used as a digestive, stimulant, for blood diseases, and against amnesia [25]. The powdered rhizome is taken orally as a condiment, tonic, calefacient and digestive [24]

The plant is used in different countries of North Africa as an antihirheumatic, diuretic, emmenagogue, and febrifuge [23]

Diuretic [25]. Root decoction against stomach disorders [26]. A decoction of the rhizome or aerial part against rheumatisms, kidney stones, uterine and menstrual pains, and abortion [24] 


\section{Cyperus rotundus L. s.l. giầd (arab)}

(PORUN - TTF2307)

CYPERACEAE
Tubers

A water potion against heart diseases

North African Countries. The tubercles are used to cure a wide
range of affections [23] In Sudan, a tuber decoction is used to treat stomach troubles and as an anthelmintic [30].

Stem galls mixed with leaves of Lawsonia inermis are powdered,

kneaded with water and applied as a hair tonic [24].

The tubers are used to increase body weight [21]

In Morocco, the plant is considered to be a cosmetic and aromatic and is used in hair care [25]

Elettaria cardamomum (L.)

cacúla

Fruits

Fruit is grounded and mixed with honey into a

Maton (PORUN - TTD8)

ZINGIBERACEAE

Additional file 9

Ephedra alata Decne. s.l.

(PORUN - TTF2310)

EPHEDRACEAE

Euphorbia guyoniana Boiss.

et Reut. (PORUN - TTF918)

Euphorbia paralias L. (PORUN

TTF922)

EUPHORBIACEAE

Ferula marmarica Asch. et

Schweinf. (PORUN - TTD22)

APIACEAE

Additional file 10

Globularia alypum L. s.l.

(PORUN - TTF2077)

GLOBULARIACEAE

Haplophyllum tuberculatum (Forssk.) A. Juss. (PORUN

TTD59; TTF2064)

RUTACEAE

Additional file 11

Hedypnois cretica (L.) Dum.

Cours. (PORUN - TTF2312)

ASTERACEAE

Hyoscyamus muticus L. subsp. falezlez (Coss.) Maire (PORUN - TTF2315)

SOLANACEAE

Jateorhiza palmata (Lam.) Miers (PORUN - TTD69;

TTF2322)

MENISPERMACEAE

Additional file 12 alenda (arab); timatrat (temahac)

lebbîn (arab)

fassuch

zréga, zrga (arab); taselrha? (berber); tidi-n-tenet (tuaregh)

Leaves and

Aerial part

decoction is used as a laxative, against intermittent fevers and topically in the cure of furuncles

sézeret er rîh (arab)

Aerial part

Laxative

sézeret er rîh (arab)

Aerial part

Against met

gungot (arab); falezlez (arab); afahlehle (temahac); bathim, buthima

zarámba influence)

Aerial part The plant is severely poisonous. The extract of the aerial part mixed with butter is used externally against rheumatic affections
Powdered seeds are used in a preparation administered as an Pohrodisiac, digestive, and stimulant. Seeds are also used as a condiment $[24,25]$

Used in Algeria, Libya, and Morocco as an anthiasthmatic, antihypertensive, astringent, and depurative as well as used against headaches and for treatment of pulmonary affections [23]

Different Euphorbia species are used in Morocco to treat skin diseases [26]

Source of gum ammoniac [35]

North African countries, branch and leaf decoctions are prepared to cure intermittent fevers, arthritis and rheumatisms and used as a depurative, diuretic, hypoglycemiant and laxative $[23,25]$. The decoction of the aerial parts is administered against constipation, fever, and mycosis [28].

A leaf infusion is used as a hypoglycemic, digestive, and laxative as well as for bilious stimulation [24]

In Egypt and Saharan territories, flowering and fruiting branches are used to cure gastro-intestinal affections, intermittent fevers, and rheumatisms. The plant is also an aphrodisiac and administered against eye and ear affections [23]

Medicinal uses not described for Maghreb and neighboring countries. Known as an edible plant in different Mediterranean countries $[36,37]$

Known as medicinal plant in Marmarica [22]. In North Sahara, a potion is drunk as a tonic [29]. The oil macerate of leaves is topically used in Tassili N'ajjer against backache, muscular cramps, spasms, and palpitation anxiety as well as to treat eye inflammation and lice [28]

Infusion in orange water is given against cardiac Its use is largely diffused in East and Central Africa as a bitter tonic, affections 


\section{Juniperus oxycedrus L. s.l. $\quad$ taga (Algeria)}

(PORUN - TTF2327)

CUPRESSACEAE

Launaea quercifolia (Desf) Pamp. (PORUN - TTF654) ASTERACEAE

Laurus nobilis L. (PORUN -

TTD47)

LAURACEAE

Additional file 13

Lawsonia inermis L. (PORUN hénna (arab); alen (berber);

- TTF1798)

LYTHRACEAE

Lepidium sativum L. s.l.

(PORUN - TTD34; TTF852)

BRASSICACEAE

Additional file 14

machinàn (arab)

rénd, rhár (arab)

anella (temahac)

habb' rsciad (arab); carabau tsc'uit (Algeria)

\section{Wood of the}

stem

Aerial part

oil) that is used against skin affections

Tunisia and Morocco, the tar produced by

antiparasitic and antiseptic for the skin [23]

Medicinal uses not described for Maghreb and neighboring countries. In Morocco, L. arborescens is used to cure diabetes and against nausea and skin troubles [21]

Dried leaves Medicinal plant (uses not described). Dried leaves are sold in the markets by herbalists

(is fruit oil has a cosmetic application for face care. An infusion of leaves and fruits is administered for dental hygiene and to cure liver, pancreas and digestive diseases. The decoction of the same parts is given to treat rheumatic pains $[24,25]$

Aerial part Astringent, vulnerary, used against dandruff and Leaves are antiseptic and astringent as well as used against eye chilblains. Abortive Fections and in the preparation of antirheumatic liniments. Flowers have insecticide properties [23]. Leaves powdered and mixed with water are applied as a hair tonic or mixed with lime mixed with water are applied as a hair tonic or mixed with lime juice as an emetic [24]. Also administered against gastric ulcer and
kidney stones [25]

Sold in the markets and used to cure cough and asthm

In North Africa, the seeds, crushed with honey, or seed flour are administered against cough and pulmonary affections, delivery difficulties, heart tonic, revulsive and also in the cure of skin troubles. The leaves are considered tonic and effective in the troubles. The leaves are considered tonic and effective in the prevention of scurvy, frequently used as a condiment $[23,25]$. The milk infusion of seeds is used to cure migraines. Seeds boiled in oil are used to treat diarrhea. Powdered seeds are externally applied for skin ulcers and warts. Seeds are also part
in the treatment of sexual impotence [24]

Aerial part The powdered plant, mixed with oil, is used for rheumatism

(PORUN - TTF1423)

Marrubium vulgare

LAMIACEAE

Matricaria aurea (Loefl.) Sch. fleia (arab); greisa (Cirenaica) Bip. (PORUN - TTD25:

TTF666)

ASTERACEAE

Additional file 15

Myrtus communis L. s.t.

(PORUN - TTD31)

MYRTACEAE

Additional file 16 rúbia, róbia (arab)

Flowering

branches

rehân, ghemmâm, gidra (arab)

Leaves and

flowers
The decoction is used against gastro-intestinal affections

The plant has many medicinal uses
Flowers have insecticide properties [23]. A leaf and stem decoction is used to treat intestinal pains, cough, and colds. Crushed leaves are used against ear pains [26]. An infusion of the aerial parts is used as an antipyretic, expectorant, antidiarrheal, tonic, bilious stimulation and for bronchitis and menstrual pains. The aerial part is also boiled with wine to obtain a syrup used as a stomachic [24,25]

n the Middle East, the plant is used as a substitute for $M$. chamomilla [39]

The plant is sold in the Algiers and Rabat markets for use against diarrhea, gastro-intestinal disorders, asthma and other respiratory ailments. It is also topically applied for painful organs. The plant is also used in perfumery and cosmetics $[23,25]$. Leaves and buds are used against hemorrhoids and skin affections. Fruits are administered for the cure of ocular disorders. An infusion of the leaves is used as a mouthwash against gingivitis and in association with walnut and mulberry in the treatment of diabetes [21].

A leaf decoction is used against cardiac and intestinal affection 26]. A leaf infusion is used against pneumonia diarrhea and to promote wound healing. For hair care, a mixture with Lawsonia inermis is locally applied [24] 
Nitraria retusa (Forssk.) Asch. gárdegh (arab); atazzim

(PORUN - TTF2317) $\quad$ (temahac)

ZYGOPHYLLACEAE

Olea europaea L. s.l. (PORUN zêt, zêt ez zitûna

OLEACEAE

Opuntia ficus-indica (L.) Mill. hindi (arab)

(PORUN - TTF2329)

CACTACEAE

\section{Orchis mascula (L.) L. s.l. sahalep}

(PORUN - TTF2326)

ORCHIDACEAE

\section{Origanum majorana L._mardqúscia (arab) \\ mardgúscia (arab)}

(PORUN - TTD41)

LAMIACEAE

Additional file 17

Origanum vulgare L. S.l.

(PORUN - TTF2303)

LAMIACEAE

Paliurus spina-christi Mill.

(PORUN - TTF2321)

RHAMNACEAE

Paronychia argentea Lam

(PORUN - TTF2301)

PARONYCHIACEAE

Peganum harmala L. (PORUN hármal (arab); bender tifli,

- TTD35; TTF2067)

bender tifin (tuaregh)

sédr, zegregh, ennab, corna

(arab); abaga, labacat

(temahac); magaria, cussulu

(Algeria)

theia el arab, theia el gebel

(Algeria)

ZYGOPHYLLACEAE

Additional file 18
Leaves

Oil

deaves are put in hot water and then

used as a poultice against swellings

Excipient of many plant drugs

Flowers

Medicinal properties (not described)

Whole plant Used in the preparation of a medicinal powder

Aerial part Against dysentery

Flowers Flowers have medicinal properties

Young shoots Anthelmintic

Leaves

Aerial part Infusion used against dysentery

Seeds $\quad$ Oil is used against headaches; burnt against mental diseases
The leaves are used in Tunisia to reduce swellings, and the ashes are used to cure infected wounds [21]

A leaf decoction is used against nervous troubles and as an anthelmintic. Powdered leaves are used in the treatment of diabetes; burnt leaves are used to cure eye affections. Olive oil is administered to cure dry cough and grippe [26]. In Morocco, it is used for mouth hygiene, stomach pains, intestinal diseases, and diabetes $[24,25]$

The powdered flower is used against stomach disorders [26]. An infusion of flowers is administered to stop diarrhea and as a diuretic. Flowers are also part of a preparation used as a calefacient [24]. In Morocco, it is also administered to cure bladder, kidney and uterus infections [25]

No medicinal use reported for Maghreb or Sahara

In the Algiers market, the plant is sold to cure eye affections [23] In Morocco, the infusion of branches is used to treat chills, fever, cough, and flatulence $[25,26]$

In Tunisia and Algeria, the leaves and flowering branches are used as a stimulant [23]

Medicinal uses not reported in Maghreb and neighboring regions. Used in the East Mediterranean region to treat respiratory circulatory and gastro-intestinal disorders [40]

Used as an antidiabetic in the East Mediterranean [41]

The plant is sold in North African markets and used for a large number of affections. In Sudan, it is used against inflammations of the head, face and mouth as well as against headache and sinusitis [31]. The leaf decoction is used against high blood pressure and hemorrhoids [21]. In Tassili N'ajjer (Algeria), a decoction of seeds is hemorrhoids [21]. In Tassili Najjer (Algeria), a decoction of seeds taken to treat a large number of affections, ranging from skin diseases to nervous disorders, including anxiety. Also used to treat diabetes, helminthiasis and jaundice. The seed decoction is externally applied against tumors, eczema and lice [28]. Similar uses are also reported for Morocco and the Northern Sahara $[25,29]$. Powdered seeds of barley and $P$. harmala are topically applied against rheumatism [21]

The seed decoction is used as a local analgesic and antirheumatic [23]. In Tassili N'ajjer (Algeria), the decoction of seeds or the aerial part of the plant can be drunk as an abortive and to cure diabetes. Externally, used to treat rheumatism and various pains [28].

Fodder appreciated in arid areas, eaten by camels, sheep and goats Tchad)
Fruits syphilis mixed with a substance called A violet, pungent beverage is a slight laxative 


\begin{tabular}{|c|c|c|c|c|}
\hline $\begin{array}{l}\text { Phoenix dactylifera L. (PORUN } \\
\text { - TTF2323) } \\
\text { ARECACEAE }\end{array}$ & $\begin{array}{l}\text { na'hla (arab); tezdit (berber); } \\
\text { tazzeit, tazeit (temahac); zui } \\
\text { (Augila) }\end{array}$ & Fruits & $\begin{array}{l}\text { The fruits are used to make an alcoholic } \\
\text { beverage to which is attributed medicinal } \\
\text { properties. }\end{array}$ & $\begin{array}{l}\text { In North African countries, the wood of the palm is used as } \\
\text { toothbrush. Dates are used as against ulcers of the genital organs } \\
\text { and as a diuretic, laxative, and tonic [23] }\end{array}$ \\
\hline $\begin{array}{l}\text { Piper retrofractum Vahl } \\
\text { (PORUN - TTD19) } \\
\text { PIPERACEAE } \\
\text { Additional file } 19\end{array}$ & dahr el filfil & Flowers & $\begin{array}{l}\text { Imported in Libya from Sudan. When mixed } \\
\text { with honey is used as an aphrodisiac }\end{array}$ & $\begin{array}{l}\text { The plant is imported from Asian countries. In Morocco, the plant is } \\
\text { known for its aphrodisiac, calefacient and magic properties [25] }\end{array}$ \\
\hline $\begin{array}{l}\text { Pistacia atlantica Desf. } \\
\text { (PORUN - TTD3; TTF16) } \\
\text { ANACARDIACEAE } \\
\text { Additional file } 20\end{array}$ & batúm (arab); tizert (berber) & Fruits & $\begin{array}{l}\text { Sold in the markets. It is chewed against } \\
\text { respiratory affections. The oil has similar } \\
\text { properties }\end{array}$ & $\begin{array}{l}\text { Leaves are used against skin affections. Fruits are used to season } \\
\text { dates. Used for tanning [23]. In Marmarica, it is used as fuel, grazing } \\
\text { and medicinal plants [22]. Burnt leaves are used in a poultice } \\
\text { against eye affections [26]. In Morocco, fruits are administered } \\
\text { against stomach-ache, whereas the gall is used for cosmetic } \\
\text { applications, against fever and stomach diseases [25] }\end{array}$ \\
\hline $\begin{array}{l}\text { Plantago afra L. s.I. (PORUN - } \\
\text { TTF2324) } \\
\text { PLANTAGINACEAE }\end{array}$ & anàm, nenàm (arab) & Whole plant & $\begin{array}{l}\text { Vulnerary. Powdered and dried is administered } \\
\text { in topical applications }\end{array}$ & $\begin{array}{l}\text { In Marmarica, used as medicinal plant [22]. In North African } \\
\text { countries, used against metabolic disorders, gastro-intestinal } \\
\text { affections, hemorrhoids, skin diseases, urinary tract disorders, and } \\
\text { venereal diseases. Fresh leaves are applied topically for poison ivy, } \\
\text { insect bites and stings [21] }\end{array}$ \\
\hline $\begin{array}{l}\text { Punica granatum L. (PORUN } \\
\text { - TTD37) } \\
\text { PUNICACEAE } \\
\text { Additional file } 21\end{array}$ & $\begin{array}{l}\text { rummân, rummâna (arab); } \\
\text { taarmunt, armun (fruit) } \\
\text { (berber); tarrumant (temahac) }\end{array}$ & Flowers & $\begin{array}{l}\text { Flowers are medicinal. Seeds are tonic and } \\
\text { aphrodisiac }\end{array}$ & $\begin{array}{l}\text { In Egypt, fruit peels are sold as an astringent; dried powdered peel } \\
\text { is sold in Morocco as an antidiabetic, antidiarrheal, antiseptic, } \\
\text { antiulcerous, astringent, and hemostatic as well as against gastro- } \\
\text { intestinal and gynecological disorders and for cleansing the teeth } \\
{[23-26]}\end{array}$ \\
\hline $\begin{array}{l}\text { Ricinus communis L. s.l. } \\
\text { (PORUN - TTD14) } \\
\text { RUTACEAE } \\
\text { Additional file } 22\end{array}$ & chèrua (arab) & Seeds & $\begin{array}{l}\text { The water infusion is a laxative (also chewed } \\
\text { seeds). Leaves are used in the preparation of } \\
\text { poultices }\end{array}$ & $\begin{array}{l}\text { Known as a medicinal plant in Marmarica [22]. In Central Sahara, } \\
\text { the seed decoction is used against fevers and headaches or } \\
\text { externally applied to cure trachoma, aphthae, and hair loss [28]. A } \\
\text { decoction is administered to treat cow jaundice [24]. In Sudan, the } \\
\text { fresh leaves are rubbed on the head to relieve headache or on the } \\
\text { legs against swellings [30] }\end{array}$ \\
\hline $\begin{array}{l}\text { Rosa damascena Mill. } \\
\text { (PORUN - TTF2325) } \\
\text { ROSACEAE }\end{array}$ & uárd (arab) & Rose buds & $\begin{array}{l}\text { The herbalists in Tripoli sell dried rose buds for } \\
\text { medicinal purposes (sciús el uárd) }\end{array}$ & $\begin{array}{l}\text { Dried flower buds are used against headache, stomach pains, } \\
\text { toothaches, and as laxative and hair tonic are sold in North African } \\
\text { markets }[23,25] \text {. Used also in the cure of numerous affection of the } \\
\text { eyes and ears [23] The flower infusion is used as a laxative. A } \\
\text { mixture with other plants is applied externally [24] }\end{array}$ \\
\hline $\begin{array}{l}\text { Rosmarinus officinalis L. } \\
\text { (PORUN - TTD16; TTF1441) } \\
\text { LAMIACEAE } \\
\text { Additional file } 23\end{array}$ & clíl (arab); uzbir, uzuer (berber) & Leaves & $\begin{array}{l}\text { The infusion is used against cough; ground } \\
\text { dried leaves in oil are vulnerary }\end{array}$ & $\begin{array}{l}\text { The leaf decoction is administered against intestinal parasites and } \\
\text { rheumatism in Central Sahara [26] as well as an emmenagogue, } \\
\text { spasmolytic against gastro-intestinal and liver disorders, diuretic, } \\
\text { carminative and sedative in Morocco [25]. A leaf infusion is also } \\
\text { prepared against tachycardia and as a cholagogue and vasopressor. } \\
\text { Leaves are also externally applied against wrinkles, muscular pains } \\
\text { and rheumatism and as a vulnerary [24]. } \\
\text { In Tunisia, rosemary leaves are used as an antispasmodic for the } \\
\text { digestive tracts and as a vermifuge. Dried leaves, ground and mixed } \\
\text { with olive oil, are put on recent circumcision wounds [21] }\end{array}$ \\
\hline
\end{tabular}




\begin{tabular}{|c|c|c|c|}
\hline $\begin{array}{l}\text { Ruta chalepensis L. (PORUN - } \\
\text { TTF2069) } \\
\text { Ruta sp. (PORUN - TTD24) } \\
\text { Additional file } 24 \\
\text { Ruta graveolens L. (PORUN - } \\
\text { TTF2309) } \\
\text { RUTACEAE }\end{array}$ & $\begin{array}{l}\text { fgél, figél (arab); issîn (temahac) } \\
\text { fgél, fesál (arab) }\end{array}$ & $\begin{array}{l}\text { Aerial part } \\
\text { Aerial part }\end{array}$ & $\begin{array}{l}\text { Sold in Tripoli market, and used against } \\
\text { rheumatic affections and ecchymosis. The sm } \\
\text { of the plant keeps the scorpions away from } \\
\text { houses } \\
\text { In Cyrenaica, a potion made with this plant i } \\
\text { administered to newborns as a tonic }\end{array}$ \\
\hline $\begin{array}{l}\text { Salvia aegyptiaca L. (PORUN } \\
\text { - TTF1370) } \\
\text { LAMIACEAE }\end{array}$ & $\begin{array}{l}\text { ra'al, sezeret el rházel (arab, ex } \\
\text { Muschler); safsaf (tuaregh) }\end{array}$ & $\begin{array}{l}\text { 1. aerial part; } \\
\text { 2. leaves }\end{array}$ & $\begin{array}{l}\text { The infusion is digestive. } \\
\text { The leaves are kept in the nose to give a fre } \\
\text { sensation }\end{array}$ \\
\hline $\begin{array}{l}\text { Schoenocaulon officinale } \\
\text { (Schltdl. et Cham.) A. Gray ex } \\
\text { Benth. (PORUN - TTF2311) } \\
\text { MELANTHIACEAE }\end{array}$ & duá ghémel & Seeds & Against lice \\
\hline $\begin{array}{l}\text { Smyrnium olusatrum L. } \\
\text { (PORUN - TTF2193) } \\
\text { APIACEAE }\end{array}$ & calch (arab) & Aerial part & Abortive \\
\hline $\begin{array}{l}\text { Tanacetum parthenium (L.) } \\
\text { Sch. Bip. (PORUN - TTF2332; } \\
\text { TTD63) } \\
\text { ASTERACEAE } \\
\text { Additional file } 25\end{array}$ & usciach & $\begin{array}{l}\text { Gum resin } \\
\text { Roots }\end{array}$ & $\begin{array}{l}\text { Imported from Marseille and sold in the } \\
\text { markets. It is dissolved in vinegar against } \\
\text { contusions or to cure furuncles } \\
\text { Medicinal properties (not described) }\end{array}$ \\
\hline $\begin{array}{l}\text { Teucrium polium L. s.l. } \\
\text { (PORUN - TTD65; TTF1389) } \\
\text { LAMIACEAE } \\
\text { Additional file } 26\end{array}$ & $\begin{array}{l}\text { giaád, zaád (arab); } \\
\text { techmezzutin (tuaregh) }\end{array}$ & Aerial part & Gastro-intestinal affections \\
\hline $\begin{array}{l}\text { Thapsia garganica L. s.l. } \\
\text { (PORUN - TTF2196) } \\
\text { BRASSICACEAE }\end{array}$ & drias (arab) & Inflorescence & Vulnerary \\
\hline $\begin{array}{l}\text { Thymus capitatus (L.) } \\
\text { Hoffmanns. et Link (PORUN - } \\
\text { TTD70; TTF1401) } \\
\text { Additional file } 27 \\
\text { Thymus mastigophorus } \\
\text { Lacaita (PORUN - TTF2328) } \\
\text { LAMIACEAE }\end{array}$ & $\begin{array}{l}\text { zaátar (arab); sótar (berber) } \\
\text { zaátar (arab); arrar? (berber) }\end{array}$ & $\begin{array}{l}\text { Leaves and } \\
\text { floral shoots }\end{array}$ & A cold infusion against cough \\
\hline
\end{tabular}

In Rabat Market, the plant is sold for use against nervous affections, and in Algiers markets, for use against vomiting and fevers of children and babies [23]. Washing with crushed leaves is used against ear pains, and leaves are smoked to keep away bad spirits [26]. In Morocco, the aerial parts are used as an abortive, for intestinal and hepatic diseases, male sterility, and vitiligo [25]. Also known as a vulnerary, emmenagogue, and spasmodic; the fresh plant is used as a scorpion and insect repellent. Leaves and seeds, boiled in olive oil, are rubbed on the skin to treat rheumatism and swellings [21]

In Marmarica, it is used as grazing plant [22]. In Tassili N'ajjer (Algeria), seeds are topically applied as an eye antiseptic. The infusion of the aerial part is a febrifuge, painkiller, and antispasmoic Also used to treat digestive troubles and infected wounds [28] Used as an insecticide in North Africa and on other continents [42]

The genus Smyrnium is included among the medicinal plants of Morocco and is mainly used as a calefacient [25,43]; the fruits are ground to powder and put in water for a cold in the chest. The decoction is recommended for headaches [44]

Used against fever, rheumatoid arthritis and migraines in the popular medicine of Africa, Europe and America [45]

Used in North Africa against dysmenorrhea [21].

in Morocco, the aerial parts are used against chill, edema, live pain and for blood cleansing [25]

The infusion of the aerial parts is used against cough and rheumatic pains. The root infusion is used to treat liver and bladder diseases, and an oil is externally applied for swelling and wrinkles [24]

Eaten as vegetable in Marmarica and also known as medicinal plant [22]. In Libya, the plant is used for coughs, as a tonic, and against skin affections [23] 


\begin{tabular}{|c|c|c|c|c|}
\hline $\begin{array}{l}\text { Trigonella foenum-graecum L. } \\
\text { (PORUN - TTF1596) } \\
\text { FABACEAE }\end{array}$ & hélba (arab) & Seeds & Against cough, febrifuge & $\begin{array}{l}\text { Cultivated and naturalized in North Africa [23]. The seed decoction } \\
\text { is used for uterine pains. Boiled seeds are also ingested as a } \\
\text { hypoglycemic, while powdered seed mixed with water are } \\
\text { externally applied as a hair tonic [24]. In Morocco, seeds are } \\
\text { considered to be blood cleansing and an aortic-palpitation } \\
\text { reconstituant [25]. In Sudan, it is administered against rheumatism } \\
\text { and dysentery as well as for cleaning the blood. It is also reputed } \\
\text { as a lactagogue [31]. In Tasili N'ajjar (Algeria), the decoction of the } \\
\text { aerial parts or seeds are used to cure diabetes, clean the blood, and } \\
\text { as a tonic and an analeptic [28]. Seed maceration is effective to } \\
\text { treat diabetes, scurvy, and digestive troubles [26] }\end{array}$ \\
\hline $\begin{array}{l}\text { Zingiber officinale Roscoe } \\
\text { (PORUN - TTF2330) } \\
\text { ZINGIBERACEAE }\end{array}$ & zéngibil, schéngibil & Roots & Aphrodisiac & $\begin{array}{l}\text { Used in North Africa for a wide range of affections [23]. In Sudan, } \\
\text { used for colds and rheumatism as well as to treat pneumonia [31] }\end{array}$ \\
\hline $\begin{array}{l}\text { Evernia furfuracea (L.) Mann } \\
\text { (PORUN - TTD56) } \\
\text { PARMELIACEAE } \\
\text { Additional file } 28\end{array}$ & sciba & $\begin{array}{l}\text { Fragments of } \\
\text { thallus }\end{array}$ & $\begin{array}{l}\text { When mixed with other species of lichens (see } \\
\text { below), it is used to prepare medicinal } \\
\text { decoctions }\end{array}$ & Medicinal uses not reported for Maghreb and neighboring regions \\
\hline $\begin{array}{l}\text { Ramalina calicaris (L.) Fr. } \\
\text { (PORUN - TTD53) } \\
\text { RAMALINACEAE } \\
\text { Additional file } 29\end{array}$ & sciba & $\begin{array}{l}\text { Fragments of } \\
\text { thallus }\end{array}$ & See Evernia furfuracea & Medicinal uses not reported for Maghreb and neighboring regions \\
\hline $\begin{array}{l}\text { Ramalina farinacea (L.) Ach. } \\
\text { (PORUN - TTD54) } \\
\text { RAMALINACEAE } \\
\text { Additional file } 29\end{array}$ & sciba & $\begin{array}{l}\text { Fragments of } \\
\text { thallus }\end{array}$ & See Evernia furfuracea & Medicinal uses not reported for Maghreb and neighboring regions \\
\hline $\begin{array}{l}\text { Usnea plicata (L.) Fries } \\
\text { (PORUN - TTD55) } \\
\text { USNEACEAE } \\
\text { Additional file } 30\end{array}$ & & $\begin{array}{l}\text { Fragments of } \\
\text { thallus }\end{array}$ & See Evernia furfuracea & Medicinal uses not reported for Maghreb and neighboring regions \\
\hline
\end{tabular}




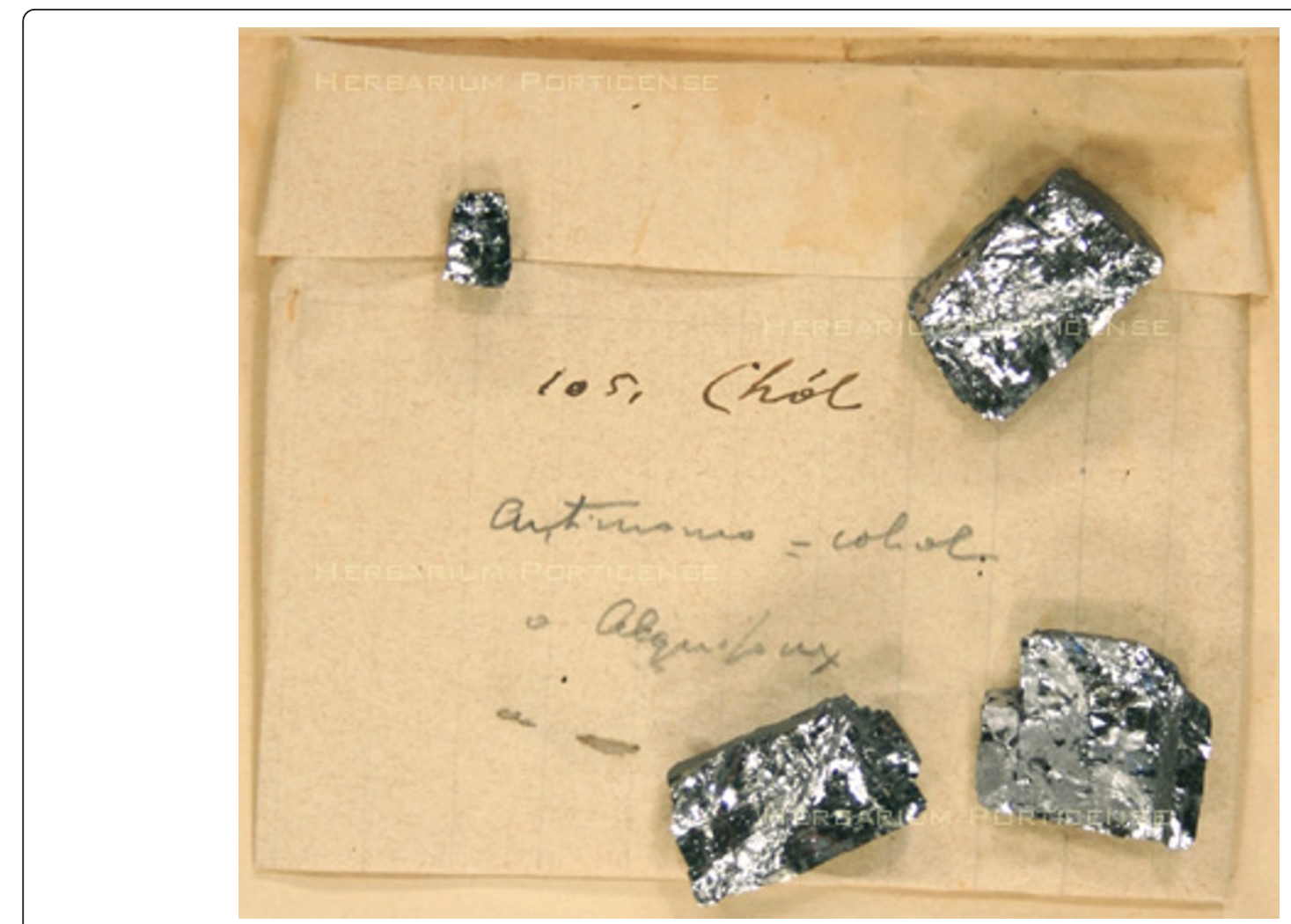

Figure 7 Antimonium (PORUN - TTD76), Tripolitania Trotter collection Drug section.

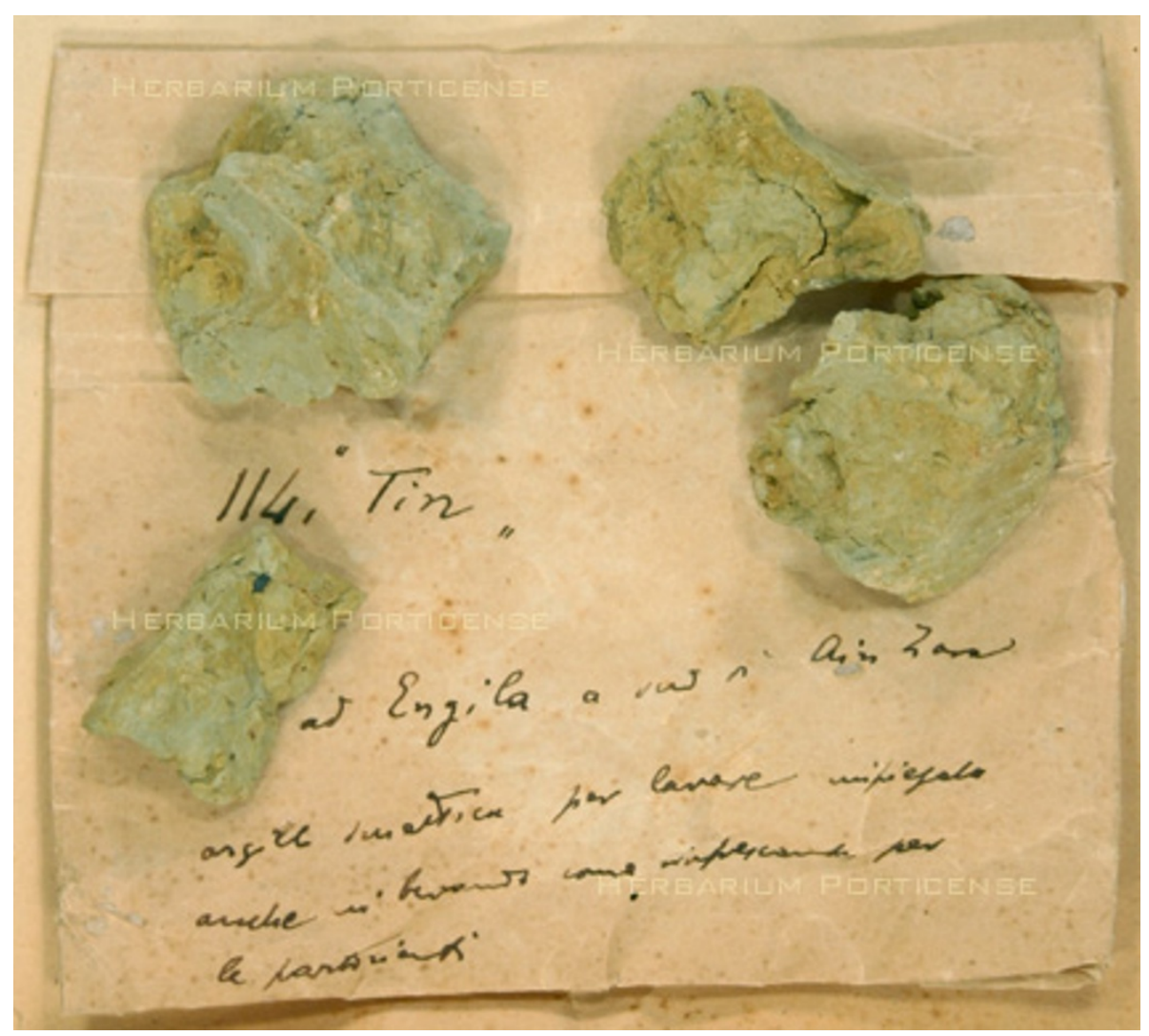

Figure 8 Clay (PORUN - TTD77), Tripolitania Trotter collection Drug section. 
therapeutic uses of each plant appear consistent over that time.

The results of this study, although based on information that needs to be confirmed by current methodologies, seem to suggest that it is possible to find a core of a shared popular medicine along the African Coast of the Mediterranean Sea, probably due to climatic, cultural and linguistic continuity.

\section{Additional material}

Additional file 1: Ajuga iva (L.) Schreb. (PORUN - TTD52), aerial part. Additional file 2: Alpinia officinarum Hance (PORUN - TTD17), rhizome.

Additional file 3: Artemisia arborescens L. (PORUN - TTD51), young shoots, flowers and leaves.

Additional file 4: Boswellia sacra Flüeckiger (PORUN - TTD39), resin of stem.

Additional file 5: Capparis orientalis Veillard in Duh. (PORUN TTD7), leaves.

Additional file 6: Cuminum cyminum L. (PORUN - TTD9), fruits. Additional file 7: Cupressus sempervirens L. (PORUN - TTD60), cones and seeds

Additional file 8: Cymbopogon schoenanthus (L.) Spreng. s.l. (PORUN - TTD79), basal part of the plant.

Additional file 9: Elettaria cardamomum (L.) Maton (PORUN - TTD8), fruits.

Additional file 10: Ferula marmarica Asch. et Schweinf. (PORUN TTD22), gum resin.

Additional file 11: Haplophyllum tuberculatum (Forssk.) A. Juss. (PORUN - TTD59), aerial part.

Additional file 12: Jateorhiza palmata (Lam.) Miers (PORUN TTD69), roots.

Additional file 13: Laurus nobilis L. (PORUN - TTD47), leaves. Additional file 14: Lepidium sativum L. s.l. (PORUN - TTD34), seeds. Additional file 15: Matricaria aurea (Loefl.) Sch. Bip. (PORUN TTD25), flowering branches and leaves.

Additional file 16: Myrtus communis L. s.l. (PORUN - TTD31), leaves and flowers.

Additional file 17: Origanum majorana L. (PORUN - TTD41), aerial part

Additional file 18: Peganum harmala L. (PORUN - TTD35), seeds. Additional file 19: Piper retrofractum Vahl (PORUN - TTD19), flowers. Additional file 20: Pistacia atlantica Desf. (PORUN - TTD3), fruits and gall-nut.

Additional file 21: Punica granatum L. (PORUN - TTD37), flowers

Additional file 22: Ricinus communis L. s.l. (PORUN - TTD14), seeds

Additional file 23: Rosmarinus officinalis L. (PORUN - TTD16), leaves.

Additional file 24: Ruta sp. (PORUN - TTD24), aerial part.

Additional file 25: Tanacetum parthenium (L.) Sch. Bip. (PORUN -

TTD63), roots

Additional file 26: Teucrium polium L. s.l. (PORUN - TTD65), aerial part.

Additional file 27: Thymus capitatus (L.) Hoffmanns. et Link (PORUN - TTD70), leaves and floral shoots.

Additional file 28: Evernia furfuracea (L.) Mann (PORUN - TTD56), thallus.
Additional file 29: Ramalina calicaris (L.) Fr. (PORUN - TTD53) and Ramalina farinacea (L.) Ach. (PORUN - TTD54), thallus.

Additional file 30: Usnea plicata (L.) Fries (PORUN - TTD55), thallus

Author details

${ }^{1}$ Department of Soil, Plant, Environmental and Animal Production Sciences, University of Naples (Federico II), Via Università, 100, 80055 Portici (NA), Italy. ${ }^{2}$ Department of Biological Sciences/Section of Plant Biology, University of Naples (Federico II), Via Foria, 223, 80139 Napoli, Italy.

\section{Authors' contributions}

The authors contributed equally to this paper. All authors read and approved the final manuscript.

\section{Competing interests}

The authors declare that they have no competing interests.

Received: 10 November 2011 Accepted: 21 January 2012 Published: 21 January 2012

\section{References}

1. De Natale A: Herbarium Porticense. In I Musei delle Scienze Agrarie. L'evoluzione delle Wunderkammern. Edited by: Mazzoleni S, Pignattelli S. Univ. degli Studi di Napoli "Federico II", Napoli; 2007:52-74.

2. De Natale A, Cellinese N: Imperato, Cirillo, and a series of unfortunate events: a novel approach to assess the unknown provenience of historical herbarium specimens. Taxon 2009, 58(3):963-970.

3. De Natale A, Marziano F: Note di etnomicologia per il territorio di Catania (Sicilia), in un manoscritto inedito di Fridiano Cavara. Micologia Italiana 2009, 38(3):51-60.

4. Galli P: La Tripolitania. Carta Geografica Dimostrativa.Edited by: Antonio Vallardi, Milano; [s.d.] (about 1912).

5. De Cillis E, Franchi S, Trotter A, Tucci F: Ricerche e studi agrologici sulla Libia. La zona di Tripoli. Ministero di Agricoltura, Industria e Commercio, Istituto Italiano d'Arti Grafiche (Bergamo); 19121.

6. Trotter A: A proposito di alcune piante del Gébel tripolitano. Bullettino dell'Orto Botanico della Regia Università di Napoli 1914, 4:235-238.

7. Trotter A: Osservazioni botaniche in Tripolitania. Rivista della Tripolitania 1924, 1(3):1-24.

8. Trotter A: Nuove osservazioni botaniche sulla Tripolitania. In La Tripolitania Settentrionale. Volume 1. (Relazione della Commissione Ministeriale per lo studio agrologico della Tripolitania). Tip. Naz. Bertero; 1913.

9. Trotter A: Flora economica della Libia. Tipografia dell'Unione Editrice, Roma; 1915

10. Heinrich M, Kufer J, Leonti M, Pardo-de-Santayana M: Ethnobotany and ethnopharmacology-interdisciplinary links with the historical sciences. Journal of Ethnopharmacology 2006, 107:157-160.

11. Sõukand R, Kalle R: Change in medical plant use in Estonian ethnomedicine: A historical comparison between 1888 and 1994. Journal of Ethnopharmacology 2011, 135:251-260.

12. Łuczaj $Ł$ : Change in the utilization of wild green vegetables in Poland since the $19^{\text {th }}$ century: A comparison of four ethnobotanical survey. Journal of Ethnopharmacology 2010, 128:395-404.

13. Łuczaj $Ł$ : Change in assumption day herbal bouquets in Poland: a nineteenth century study revisited. Economic Botany 2011, 65(1):66-75.

14. Fossi Innamorati T: Notizie di medicina popolare africana nell'Erbario Tropicale di Firenze. Webbia 1973, 28(1):81-133

15. Sandberg F, Perera-Ivarsson P, Rushdey El-Seedi H: A Swedish collection of medicinal plants from Cameroon. Journal of Ethnopharmacology 2005, 102:336-343

16. Fowler GL: Italian colonization of Tripolitania. Annals of Associaton of American Geographers 1972, 62(4):627-640.

17. Principi P: I principali tipi di suolo della Tripolitania. Rivista di Agricoltura Subtropicale e Tropicale 1947, 41:195-201.

18. Fantoli A: La siccità in Libia. Reale Accademia dei Lincei 1935, 4(2):1-92

19. Conservatoire et Jardin botaniques de la Villle de Genève e South African National Biodiversity Institute: African Flowering Plants Database.[http:// 
www.ville-ge.ch/musinfo/bd/cjb/africa/, (version 3.2, last update 01.12.2009) Pretoria.

20. WCSP: World Checklist of Selected Plant Families. Facilitated by the Royal Botanic Gardens, Kew [http://apps.kew.org/wcsp/home.do], (accessdate 2011-04-01)

21. The World Conservation Union Centre for Mediterranean Cooperation Parque Tecnológico de Andalucia: Medicinal Plants of North Africa.[http:// data.iucn.org/places/medoffice/nabp/database/], (last update 2005).

22. Le Houérou HN: Plant diversity in Marmarica (Libya \& Egypt): a catalogue of the vascular plants reported with their biology, distribution, frequency, usage, economic potential, habitat and main ecological features, with an extensive bibliography. Candollea 2004, 59(2):259-282.

23. Boulos L: Medicinal plants of North Africa. References Publications Inc; 1983.

24. Merzouki A, Ed-derfoufi F, Molero Mesa J: Contribution to the knowledge of Rifian traditional medicine. II: Folk medicine in Ksar Lakbir district (NW Morocco). Fitoterapia 2000, 71:278-307.

25. Bellakhdar J, Claisse R, Fleurentin J, Younos C: Repertory of standard herbal drugs in the Moroccan pharmacopoea. Journal of Ethnopharmacology 1991, 35:123-143.

26. El-Hilaly J, Hmammouchi M, Lyoussi B: Ethnobotanical studies and economic evaluation ofmedicinal plants in Taounate province (Northern Morocco). Journal of Ethnopharmacology 2003, 86:149-158.

27. De Boer HJ: African plants as antipathogen agents: efficacy and clincal evidence. In Botanical Medicine in clinical practice. Edited by: Watson RR Preedy VR. CABI, Cromwell Press, Trowbridge, UK; 2008:13-19.

28. Hammiche V, Maiza K: Traditional medicine in Central Sahara: Pharmacopoeia of Tassili N'ajjer. Journal of Ethnopharmacology 2006, 105:358-367.

29. Maiza K, Brac De La Perrière RA, Hammiche V: Pharmacopée traditionnelle saharienne: Sahara septentrional. Actes du ze Colloque Européen d'Ethnopharmacologie et de la 11e Conférence internazionale d'Ethnomédecine, Heidelberg, 24-27 mars 1993, Heidelberg. Medicines and Foods: The Ethnopharmacological Approach. Heilmittel und Nahrungsmittel aus ethnopharmakologischer Sicht, Heidelberg, AGEM 1993, 169-171.

30. El-Kamali HH, El-Kalifa KF: Folk medicinal plants of riverside forest of the Southern Blue Nile district, Sudan. Fitoterapia 1999, 70:493-497.

31. Hussein Ayoub SM, Baerheim Svendsen A: Medicinal and aromatic plants in the Sudan: usage and exploration. Fitoterapia 1981, 52:243-246.

32. Basar S: Phytochemical investigation on Boswellia species. PhD thesis, University of Hamburg; 2005.

33. Hussein Kotb FT: Medicinal plants in Libia. Arab Encyclopedia House, Beirut-Lebanon; 1985.

34. El-Darier SM, El-Mogaspi FM: Ethnobotany and relative importance of some endemic plant species at El-Jabal El-Akhdar region (Lybia). World Journal of Agricultural Sciences 2009, 5(3):353-360.

35. Stapf O: The gums ammoniac of Morocco and the Cyrenaica. Bullettin of Miscellaneous Information. Royal Botanic Garden, Kew 1907, 10:375-388.

36. Ghirardini MP, Carli M, del Vecchio N, Rovati A, Cova O, Valigi F, Agnetti G, Macconi M, Adamo D, Traina M, Laudini F, Marcheselli I, Caruso N, Gedda T, Donati F, Marzadro A, Russi P, Spaggiari C, Bianco M, Binda R, Barattierie E, Tognacci A, Girardo M, Vaschetti L, Caprino P, Sesti E, Andreozzi G, Coletto E, Belzer G, Pieroni A: The importance of a taste. A comparative study on wild food plant consumption in twenty-one local communities in Italy. Journal of Ethnobiology and Ethnomedicine 2007, 3:22[http://www. ethnobiomed.com/content/3/1/22].

37. Nebel S, Heinrich M: Ta Chòrta: A Comparative Ethnobotanical-Linguistic Study of Wild Food Plants in a Graecanic Area in Calabria, Southern Italy. Economic Botany 2009, 63(1):78-92.

38. Botsaris SA: Plants used traditionally to treat malaria in Brazil: the archives of Flora Medicinal. Journal of Ethnobiology and Ethnomedicine 2007, 3:18[http://www.ethnobiomed.com/content/3/1/18].

39. Lev E, Amar Z: "Fossils" of practical medical knowledge from medieval Cairo. Journal of Ethnopharmacology 2008, 119:24-40.

40. Everest A, Ozturk E: Focusing on the ethnobotanical uses of plants in Mersin and Adana provinces (Turkey). Journal of Ethnobiology and Ethnomedicine 2005, 1:6[http://www.ethnobiomed.com/content/1/1/6/.

41. Hamdan II, Afif FU: Studies on the in vitro and in vivo hypoglycemic activities of some medicinal plants used in treatment of diabetes in Jordanian traditional medicine. Journal of Ethnopharmacology 2004, 93(1):117-121.
42. Isman MB: Botanical insecticides, deterrents, in modern agriculture and an increasingly regulatedworld. Annual Reviews Entomology 2006, 51:45-66.

43. Lahsissene H, Kahouadji A, Tijane M, Hseini S: Catalogue des plantes medicinales utilisees dans la region de Zaër (Maroc Occidental). Lejeunia 2009, 186:1-25, n.s.

44. Fogg W: The wares of Moroccan folk-doctor. Folklore 1941, 52(4):273-303.

45. Setty $A R$, Sigal $A H$ : Herbal medications commonly used in the practice of rheumatology: Mechanisms of action, efficacy, and side effects. Semin Arthritis Rheum 2005, 34:773-784.

46. González-Tejero MR, Casares-Porcel M, Sánchez-Rojas CP, RamiroGutiérrez JM, Molero-Mesa J, Pieroni A, Giusti ME, Censorii E, de Pasquale C, Della A, Paraskeva-Hadijchambi D, Hadjichambis A, Houmani Z, ElDemerdash M, El-Zayat M, Hmamouchi M, ElJohrig S: Medicinal plants in the Mediterranean area: Synthesis ofthe results of the project Rubia. Journal of Ethnopharmacology 2008, 116:341-357.

47. Uphof CJTh: Dictionary of economic plants.Edited by: Cramer J. New York; 1968:

48. Romagni JG, Dayan FE: Structural diversity of lichen metabolites and their potential use. In Advances in microbial toxin research. Edited by: Uphadhay RK. Kluwer Academic/Plenum Press, New York; 2002:151-158.

49. Malhotra S, Subban R, Singh A: Lichens-Role in Traditional Medicine and Drug Discovery. The Internet Journal of Alternative Medicine 2008, 5(2) [http://www.ispub.com/ostia/index.php?xmlFilePath=journals/ijam/vol5n2/ lichen.xml].

50. Upreti DK, Divakar PK, Nayaka S: Commercial and ethnic use of lichens in India. Economic Botany 2005, 59(3):269-273.

51. Forrest RD: Early history of wound treatment. Journal of the Royal Society of Medicine 1982, 75:198-205.

52. Roselli A: Breve storia del silfio. Annali di Archeologia e storia antica 2001, 8:11-20.

53. Hanlidou E, Karousou R, Kleftoyanni V, Kokkini S: The herbal market of Thessaloniki ( $\mathrm{N}$ Greece) and its relation to the ethnobotanical tradition. Journal of Ethnopharmacology 2004, 91(2-3):281-299.

54. Hare CP: Indian medicinal plants: an illustrated dictionary. Springer Verlag Berlin, Heidelberg; 2007.

55. Simonati CN, Helmy MA, Moise G: Production of medicinal plants in Asia. Scientific Papers Management, Economic Engineering in Agriculture and Rural Development 2009, 9(1):135-138.

56. Groenewegen AW, Knight DW, Heptinstall S: Progress in medicinal chemistry of the herb feverfew. In Progress in Medicinal Chemistry. Volume 29. Edited by: Ellis GP, Luscombe DK. Elsevier; 1991:217-238.

57. Lily Beck Y: Dioscorides. De Materia Medica. Altertumswissenschaftliche Texte und Studien 38. Hildesheim: Olms; 2005.

doi:10.1186/1746-4269-8-4

Cite this article as: De Natale and Pollio: A forgotten collection: the Libyan ethnobotanical exhibits (1912-14) by A. Trotter at the Museum $\mathrm{O}$. Comes at the University Federico II in Naples, Italy. Journal of Ethnobiology and Ethnomedicine 2012 8:4.

\section{Submit your next manuscript to BioMed Central and take full advantage of:}

- Convenient online submission

- Thorough peer review

- No space constraints or color figure charges

- Immediate publication on acceptance

- Inclusion in PubMed, CAS, Scopus and Google Scholar

- Research which is freely available for redistribution

Submit your manuscript at www.biomedcentral.com/submit
C Biomed Central 